\title{
SOLETRAS

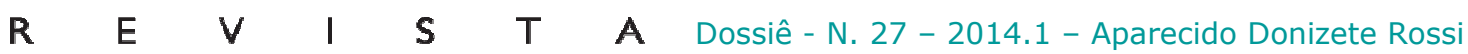 \\ Antes de Otranto: apontamentos para uma pré-história do Gótico na literatura
}

\author{
Aparecido Donizete Rossi ${ }^{1}$ \\ Universidade Estadual Paulista
}

\begin{abstract}
Resumo: Partindo-se da observação de Ariovaldo Vidal, em sua apresentação à tradução brasileira de $O$ castelo de Otranto, na qual o crítico afirma que as raízes do Gótico estavam espalhadas pela história literária e social esperando que alguém (Horace Walpole) as recolhesse para criar um novo gênero literário, e agregando a essa observação o imaginário, pretende-se realizar, no presente texto, alguns breves apontamentos sobre quais seriam, possivelmente, as raízes aos quais Vidal se refere. Recorrendo a uma reflexão sobre as Trevas como semi-conceito, em boa parte inspirada por Fred Botting em Gothic (2014), intenta-se buscar os primórdios da ficção gótica em textos de Homero, Virgílio, Dante e Milton.
\end{abstract}

Palavras-chave: Gótico. Imaginário. Literatura inglesa. Literatura clássica.

Em sua introdução à tradução brasileira do primeiro romance gótico, Ariovaldo Vidal faz uma observação sobre o gênero literário do assustador que merece uma reflexão mais atenta: "como todo novo gênero, suas raízes estavam espalhadas pela história literária e social, esperando que alguém as recolhesse e criasse a nova forma” (VIDAL, 1994, p. 7). Vidal não se refere apenas à literatura inglesa, a qual pertence $O$ castelo de Otranto (1764), mas a todas as literaturas e culturas ocidentais, nas quais as raízes da ficção de terror e horror surgiram, se espalharam e cresceram, durante séculos, em meio às frestas das artes e sociedades até que Horace Walpole as recolhesse e lhes desse um nome arquitetônico e, consequentemente, uma arquitetura: Gótico. Enquanto gênero literário, o Gótico emerge em 1764 na Inglaterra como um fazer artístico que toma o medo como elemento estético. As raízes que possibilitaram tal emergência já estavam há muito espalhadas e fortemente entranhadas não apenas na história literária e social do ocidente, mas também no seu inconsciente coletivo e individual, no seu imaginário, como condição inexorável de sua própria existência, pois não existiria ocidente ou oriente, natureza e cultura, filosofia e ciência, ontologia e epistemologia sem o medo ou, talvez mais propriamente, sem as Trevas.

\footnotetext{
${ }^{1}$ Graduado em Letras (Português/Inglês) pela UNESP Faculdade de Ciências e Letras de Araraquara (2003), Mestre em Estudos Literários pela mesma universidade (2006) e Doutor em Estudos Literários também pela UNESP Araraquara (2011). Atua em Letras, na área de Literaturas de Língua Inglesa, e desenvolve pesquisas principalmente sobre as Manifestações do Gótico na Literatura, a vida e a obra de Kate Chopin, Literatura e Desconstrução, Literatura e Psicanálise e Literatura e Feminismo. 


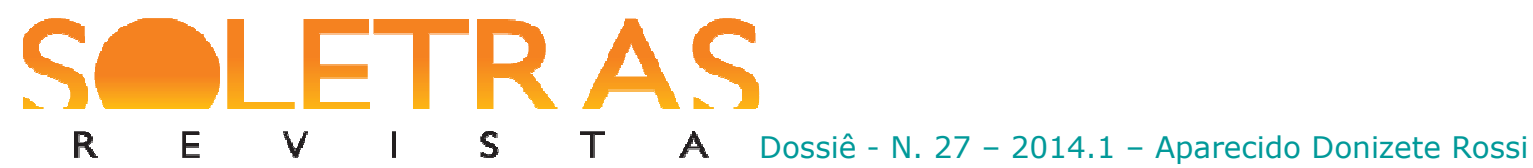

São algumas dessas raízes literárias do Gótico que se pretende desenterrar aqui para a proposição de uma reflexão sobre esse fazer literário dentro de dois eixos interpretativos: primeiramente, o de que o Gótico não é uma questão pontual em meio às diversas questões do fazer literário e da teoria e crítica literárias, tampouco apenas um elemento de ordem temático-estrutural exoticamente localizado em uma dada literatura (a britânica) e em um dado momento histórico (1764 - 1824), mas sim um modo de abordar e interpretar a existência humana, uma maneira de apreender a realidade por meio do lado sombrio do imaginário, um meio de (auto) conhecimento dos limites da lógica e da racionalidade; em segundo lugar, o de que o Gótico, por trabalhar com a estética do medo e, com isso, se constituir em um fazer literário e em um modo de pensar a própria literatura e, consequentemente, a existência, encontra sua sustentação, sua força contaminadora e seu poder disseminador não naquilo que é o medo, pois o medo não é, mas sim está, já que se articula como efeito. O Gótico se sustenta, contamina e se dissemina na literatura, nas demais artes, na cultura e na história por meio da atemporalidade das Trevas, que aqui serão tomadas como semiconceito para apontar e refletir sobre uma possível (contra)tradição da ficção de terror e de horror anterior à emergência do romance gótico.

As Trevas, portanto, constituem o vetor desses dois eixos interpretativos, um vetor eminentemente imaterial e intangível, perigoso e desarticulador, que pode ser tomado como o palimpsesto sobre o qual todas as formas de ficção que trabalham com o assustador foram e continuam sendo inscritas. Assim, são as Trevas que alimentam as raízes de uma longa tradição literária cujo desenvolvimento culminou no surgimento do romance gótico na Inglaterra setecentista. Por isso, da mesma forma que se vai utilizá-las, neste estudo, para apontamentos e reflexões sobre uma literatura das sombras anterior à emergência desse tipo de romance, poder-se-ia fazer o mesmo movimento para pensar uma disseminação do sombrio na ficção posterior à emergência do romance gótico e, para além disso, tecer considerações sobre possíveis futuros desse tipo de ficção, uma vez que as Trevas são, ao que tudo leva a crer, o princípio aporeticamente (des) agregador de todas as formas de arte que trabalham com o assustador e com o lado sombrio do humano.

\section{As Trevas como semiconceito}

Há muito se sabe que é o medo que engendra, estética e teoricamente, a ficção gótica. Sentimento ancestral, tão antigo e poderoso quanto o amor, constitui-se na manifestação do 


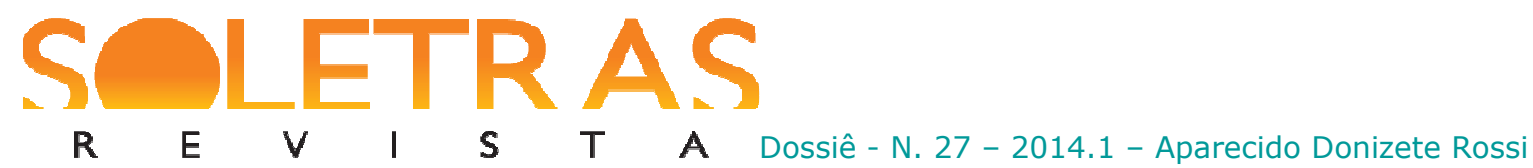

lado irracional e incontrolável da mente e do espírito humanos em face de qualquer coisa, ser, situação ou conceito que ameace a vida ou a sanidade. Sua essência é ambígua, pois o medo é, em parte, instintivo, irradiado de um recôndito remoto e inacessível da psique, por isso muitas vezes inexplicável, e, em parte, fabricável e manipulável, uma peça que a psique prega aos olhos e à consciência, mas também um conjunto de técnicas sóciopolíticas e discursivas que objetivam a subjugação do outro por meio da disseminação do terror e do horror. Por sua vez, terror e horror, juntos do pavor e da abjeção, são as manifestações articuladas do medo, sua maquinaria do assustador: é por meio deles que esse sentimento se torna um acontecimento psicofísico. Em outras palavras, terror, horror, pavor e abjeção são as estruturas pelos quais o medo pode ser racionalizado. Todavia, ao mesmo tempo e de modo misterioso, eles são também indistintamente confundidos com o próprio medo, se tornam o medo, são o medo. Por isso, paradoxalmente, esses quatro aspectos também são os articuladores da emergência do assustador enquanto manifestação do irracional e do incontrolável, do inacessível, do mistério irredutível inerente à própria existência humana. Em suma, eles desvelam o medo, mas não permitem um acesso ao seu em si. Terror, horror, pavor e abjeção são médiuns, caminhos de mão dupla ou entrecaminhos, desvios, entre o humano e o elemento assustador, seja esse elemento interno ou externo à psique. Dentro dessa perspectiva, o medo parece ser um sentimento "original”, datável e estruturável, da condição humana. No entanto, raramente se menciona que ele é, também, um efeito, um médium possibilitado por algo não datável e não estruturável: as Trevas.

A cosmogonia presente na mitologia grega arcaica ensina que, no princípio, havia o Caos. Inexplicavelmente, o próprio Caos gerou um princípio organizador que o ressignificou e, dessa ressignificação, surgiram forças elementares: Gaia (o espírito da Terra), Eros (o amor primordial), Tártaro (a treva primordial), Érebo (a escuridão) e Nix (a noite). Chama à atenção, nessa estrutura cosmogônica, a presença de três personificações distintas para o que atualmente é entendido, tornado conceito, via língua e cultura latinas, como sinônimos de uma mesma coisa: Tenebra - "escuridão, trevas, noite" (FARIA, 1955, p. 906). Diferentemente dos olhos latinos, aos olhos dos gregos arcaicos as Trevas têm tonalidades ou, mais adequadamente, gradações, as quais indiciam sentidos e percepções diferentes daquilo que é obscuro: o escuro absoluto, a treva que primeiro existiu, anterior a qualquer forma de existência e inacessível, onde a luz não é concebível ou possível (Tártaro); o escuro, o aspecto visível ou acessível das Trevas, o vácuo que serve de pano de fundo às estrelas, a não-luz que 


\section{SOLETR AS \\ R E V I $\quad$ S $\quad$ T A Dossiê - N. 27-2014.1-Aparecido Donizete Rossi}

se opõe ou pressupõe a luz (Érebo); e a sombra, o momento em que as Trevas são contornadas ou dão contorno à luz, a noite onde o escuro domina mas não é absoluto, o céu estrelado e/ou enluarado (Nix).

Nessa cosmogonia, Érebo é irmão gêmeo de Nix e, da relação incestuosa entre ambos, surgem o Éter (a luz) e Hemera (o dia). É interessante notar que, nessa forma arcaica de pensar a existência, a luz e o dia não são opostos à escuridão e à noite, mas por elas gerados; por outro lado, e paradoxalmente, para o grego arcaico as Trevas são primordiais, primeiros desdobramentos do Caos, aquilo que possibilitou a existência, enquanto os princípios da Luz são secundários, posteriores, não participantes da arquitetura primeva do Cosmos, mas já efeitos dessa arquitetura, resultantes da negatividade absoluta causada pela relação incestuosa entre duas abstrações das Trevas. Note-se que, nesse modo mítico de apreender, entender e interpretar o mundo, a Luz é o princípio negativo, não as Trevas, uma vez que elas são, de modo ambíguo, uma espécie de proteção contra os excessos da Luz (consciência, sanidade e verdade) e a ameaça aos princípios delimitadores característicos da Luz (lógica, razão e realidade). Trevas e Luz relacionam-se, portanto, sob a égide da transgressão, da contradição, da ambiguidade, o jogo entre limitar e ultrapassar os limites: o Caos que transgride a si mesmo e gera um princípio de organização que lhe é, ao mesmo tempo, contraditório e genético, mas que lhe concede um contorno, um limite, a possibilidade de sua definição e, consequentemente, a possibilidade de sua própria transgressão; o incesto entre dois princípios de Trevas, do qual resulta a Luz que lhes é, também, ao mesmo tempo, contraditória e genética, limitadora e definidora, a possibilidade se suas próprias delimitações e transgressões.

Delimitação e transgressão são os elementos irredutíveis, os impulsos centrípeto e centrífugo das Trevas e da Luz, as quais parecem manter uma relação para sempre, ou sempre-já, diferida, ou seja, "coisas que são tão heterogêneas ainda que em uma relação de contaminação e coincorporação teratológica"” (DERRIDA, 1990, p. 67). Delimitação e transgressão, Luz e Trevas, não se opõem, não se relacionam hierarquicamente, não se mesclam e não lançam anátemas umas às outras. Elas se permeiam sem se misturar, se definem mutuamente sem se opor, contaminam-se sem se destruir, estão uma em suspenso dentro da outra, coincorporam-se teratologicamente; e é somente nessa chave de entendimento que podem ser pensadas epistemologicamente não como conceitos, o que

\footnotetext{
${ }^{2}$ As traduções das citações deste texto de Derrida e dos textos de Botting e Johnson são do autor deste estudo. SOLETRAS, N. 27 (jan.-jun. 2014) ISSN: 2316-8838 


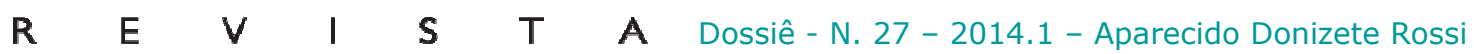

pressuporia apenas a delimitação e a Luz, mas como semi-conceitos, conceitos que não se fixam em preconizações inteiramente fechadas, mas que se abrem à significação infinita, tornam-se infixos no exato instante em que iriam se fixar. Em outras palavras,

A transgressão não está, portanto, para o limite como o negro está para o branco, o proibido para o permitido, o exterior para o interior, o excluído para o espaço protegido da morada. Ela está mais ligada a ele por uma relação em espiral que nenhuma simples infração pode extinguir. Talvez alguma coisa como o relâmpago na noite que, desde tempos imemoriais, oferece um ser denso e negro ao que ela nega, o ilumina por dentro e de alto a baixo, deve-lhe entretanto sua viva claridade, sua singularidade dilacerante e ereta, perde-se no espaço que ela assinala com sua soberania e por fim se cala, tendo dado um nome ao obscuro (FOUCAULT, 2009, p. 33).

O gesto dessa abertura, a transgressão propriamente dita daquilo que possibilita o ato de transgredir, a "relação em espiral que nenhuma simples infração pode extinguir", é o que se entende, neste estudo, como Trevas, e o medo, do modo como mencionado mais acima, é seu efeito contaminador, disseminador e incontrolável, aquilo que a permeia, que nela é e está, mas também, e ao mesmo tempo, aquilo que se constitui em algo outro, em sua alteridade, o reflexo que mostra o que ela não é. A ficção gótica, ao esteticizar o medo, ritualiza as Trevas, torna-as um modo teórico-crítico de conhecimento da existência e um elemento moderador da racionalidade, da lógica e do realismo. $\mathrm{O}$ medo é o agente que distorce razão, lógica e real, e, com seu poder alucinante e incontrolável, faz emergir as Trevas, as quais assumem os contornos da ficção gótica, na qual a força de sua manifestação é salvaguardada pelos poderes ilimitados da representação, aquilo que não é nem o real, nem o irreal e nem o ilusório, mas o simulacro, a característica fundamental do que se entende por ficção. Desse modo, as Trevas são somatizadas, corporificam-se na materialidade e na textualidade de cada obra que pertence à tradição do Gótico. É esse entendimento que leva Fred Botting (2014), um dos principais teóricos e críticos contemporâneos da ficção de terror e horror, a afirmar que

As Trevas - uma ausência da luz associada aos sentidos, à segurança e ao conhecimento - caracterizam as aparências, os ânimos, as atmosferas e as conotações do gênero. Os textos góticos são, declaradamente, porém de modo ambíguo, irracionais, retratando distúrbios de sanidade e de segurança que vão desde crenças supersticiosas em fantasmas e demônios, demonstrações de paixões incontroláveis, emoções violentas ou o fantasioso até retratos de perversões e obsessões. Além disso, se o conhecimento está associado a procedimentos racionais de indagação e entendimento baseados na realidade natural e empírica, então as convenções góticas perturbam as fronteiras do conhecido e conjuram fenômenos sobrenaturais obscuros, as "Artes das Trevas", formas alquímicas, arcanas e ocultas normalmente 


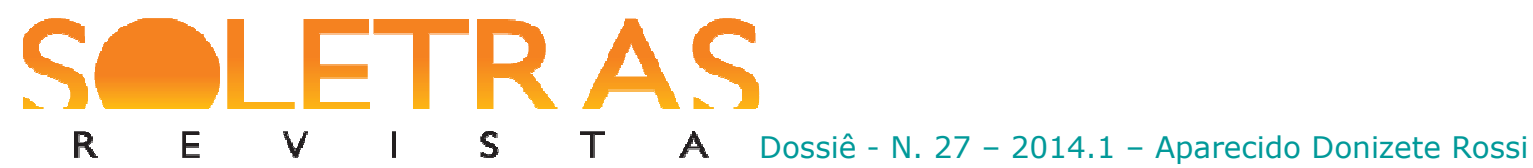

caracterizadas como ilusão, aparição, engodo. Desconectados de uma ordem natural das coisas preconizada pelo realismo, os vôos de imaginação góticos sugerem a possibilidade do sobrenatural, o mistério, o mágico, $\mathrm{o}$ maravilhoso e a monstruosidade (BOTTING, 2014, p. 2).

Para além dessa compreensão, Botting (2014, p. 32) admite que, por meio da ficção gótica, as "Trevas permitem a uma pessoa apreender a alma dentro de si e expandir a mente pela produção de uma consciência de seu próprio potencial divino”. As Trevas são, nesse sentido e de modo aporético, uma forma epifânica, quase religiosa, de iluminação contida na ficção gótica e, por conseguinte, na própria existência, pois "os pensamentos que encorajam estão no poder visionário e místico da escritura, não para produzir entendimento moral, mas para evocar sentimentos intensos" (BOTTING, 2014, p. 33).

As Trevas são atemporais. Logo, tornam o medo e sua ficcionalização também atemporais, o que é um modo sistemático de afirmar que o Gótico não se restringe exclusivamente à literatura inglesa do final do século XVIII e início do XIX, e nem se constitui em um modismo ou uma onda passageira que, vez ou outra, retorna nos contextos das literaturas ocidentais. O Gótico, dentro de sua condição de gênero literário possibilitado pelas Trevas e delas guardião e agente disseminador, sempre existiu e manifesta-se já nos primeiros textos da literatura ocidental, o que indica que as Trevas estão entre os princípios fundadores da literatura e das artes ocidentais, claro indício de que elas também estão inexoravelmente impregnadas na própria instauração da humanidade do humano e dos conceitos de civilização, História e imaginário. As Trevas, ao contrário do que preconizaram (e ainda preconizam) o Cristianismo, o Iluminismo, o Positivismo e o Realismo, são tão fundadoras do Ocidente quanto a Luz; mais do que isso, elas são, aporeticamente, o que possibilitou a Luz. Todavia, diferente da Luz, as Trevas não excluem e nem segregam, mas (des) agregam. São esses aspectos — o fundador, o possibilitador e o (des) agregador — que se pretende ressaltar, e sobre os quais se pretende refletir, com os apontamentos que seguem para uma pré-história do Gótico na literatura.

\section{Antes de Otranto}

\subsection{A Nekyia}

A raiz mais antiga da ficção gótica, o filamento que primeiro surgiu da atemporalidade das Trevas seminais, está em um dos dois textos fundadores da literatura e da cultura 


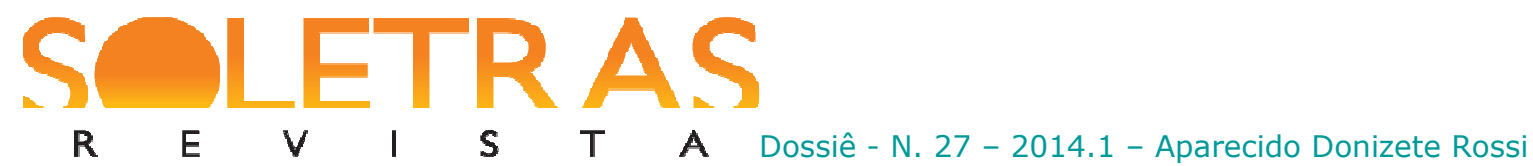

ocidentais, no episódio conhecido como a Nekyia de Odisseu, no canto XI da Odisseia, de Homero. Nekyia ( $\dot{\eta}$ vékvı $\alpha$ ) designa, na ritualística, no culto e na literatura dos antigos gregos, um rito por meio do qual as almas dos mortos eram conjuradas para serem questionadas sobre o futuro. Trata-se, portanto, de um tipo de necromancia - do grego veкрós (nekrós), "corpo morto", e $\mu \alpha v \tau \varepsilon i ́ \alpha$ (manteía), "profecia", "divinação" ou "adivinhação" —, a prática comum na Grécia antiga de profetizar por meio da consulta aos cadáveres dos mortos, os quais tinham seus espíritos, então já separados da matéria, novamente invocados a habitá-la por alguns momentos para relatar informações sobre o pós-vida, o presente, o passado e o futuro.

A palavra "Nekyia" está, como se pode notar, na raiz mais arcaica da palavra "necromancia", a cujo significado empresta o elemento imaterial (o "conjurar o espírito"), e é importante observar que, diferentemente do uso que Jung e seus seguidores fazem do conceito na Psicologia Analítica ${ }^{3}$, Nekyia não é equivalente à conjunção dos conceitos de Katabasis (a descida de um ser vivo ao mundo dos mortos) e Anabasis (o retorno de um ser vindo do mundo dos mortos), mas sim uma invocação dos espíritos dos mortos a se manifestarem no mundo dos vivos, uma espécie de abertura momentânea dos portões do Hades em resposta a um ritual mágico, um levantar proposital (conjurado por alguém) e muito breve do véu de Ísis pelo qual os espíritos podem vir para o lado dos vivos para se comunicarem. É dentro desse entendimento que a cena da Nekyia de Odisseu é aqui lida:

[...] e eu [Odisseu], arrancando da espada cortante de junto da coxa, um fosso abri, que de todos os lados um côvado mede, e libações, à sua volta, fizemos a todos os mortos: primeiramente, de mel misturado; depois, de bom vinho; de água a terceira, espalhando farinha por cima de tudo. Férvidos votos alcei às cabeças exangues dos mortos, de, quando em Ítaca, em casa, uma vaca imolar-lhes estéril, a de melhor aparência, queimando preciosos objetos, e que a Tirésias, à parte, um carneiro, também, mataria, negro sem mancha, o que em nossos rebanhos os mais excelesse. Tendo assim, pois, dirigido meus votos ao coro dos mortos, tomo as duas reses e em cima do fosso as mantenho cortando-lhes logo o pescoço. Escorreu sangue negro. Em tropel afluíram, do Érebo escuro provindas, as almas de inúmeros mortos, moços e moças, e velhos em males há muito experientes, e virgens tenras, há pouco, somente, do mal sabedoras. Muitos guerreiros afluem, por lanças de bronze feridos em duros prélios, que manchas de sangue nas armas ostendem. Inumeráveis, à volta do fosso, com grande alarido correm de todos os lados; o pálido Medo me tolhe.

\footnotetext{
conceitos de Katabasis+Anabasis.

${ }^{3} \mathrm{Na}$ Psicologia Analítica, o conceito de Nekyia é utilizado, quase que indistintamente, como sinônimo dos 
Os companheiros, depois, exortei, ordenando que as reses, que estavam mortas no chão, pelo bronze cruel abatidas, logo queimassem, depois de esfolá-las e rogos ter feito a Hades, o deus poderoso, e à terrível e horrenda Perséfone. (HOMERO, 2001, p. 190 - 191).

Com essa conjuração dos mortos por meio de um ritual que se pode entender, atualmente, como magia negra, o herói Odisseu, exemplo de mente lógica, general estrategista dos aqueus, protegido de Atena, a própria deusa do conhecimento, torna-se um necromante e, com esse gesto, instaura, na aurora da literatura, da cultura e das artes ocidentais, no reino dos mitos, a relação intercambiável e irredutível entre as luzes do conhecimento, o $\lambda o ́ \gamma o \varsigma$ (Logos), e as Trevas. Odisseu está em busca do caminho de casa e navega há muito tempo sem encontrá-lo. É Circe, irmã do terrível Eetes e tia de Medeia, aquela que é o arquétipo da feiticeira, quem orienta o herói a procurar os confins do mundo para, por meio da Nekyia, conversar com Tirésias, o ser que, na sua cegueira, vê o invisível. O que Odisseu busca ao realizar um ritual de magia negra no qual invoca Hades e Perséfone, os dois deuses mais temidos do panteão grego, os únicos que não dispunham de templo de adoração, não é apenas

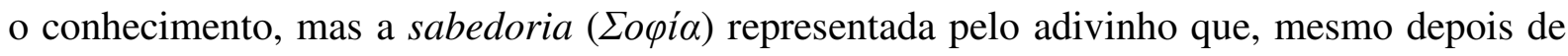
morto, é capaz de ver o que não é dado vislumbrar a nenhum vivente, seja ele deus, semideus ou mortal.

Um aspecto inusitado que chama a atenção na Nekyia homérica são seus elementos ritualísticos, particularmente as libações em torno do fosso cavado por Odisseu, fosso que representa a abertura do Hades, uma vez que, de acordo com a tradição grega, tudo que está abaixo da superfície da terra é propriedade do irmão mais velho de Zeus, inclusive a própria terra e seus tesouros (daí Hades ser denominado, já pelos gregos, de Plutão, "o rico”). Mel, vinho, água, farinha e, por fim, sangue são aspergidos em torno da cova, ou seja, comida e bebida para os mortos, bem como energia vital (sangue), o que implica na acepção de que os mortos podem sorver forças de alimentos dos vivos, pois precisam dessas forças, fontes de energia vital, para o processo de vinda do mundo dos mortos para o mundo dos vivos. Ao mesmo tempo, está conotado no ritual que alguns alimentos e bebidas específicos, junto do sangue, exercem atração sobre os mortos ou também existem em seu mundo, ou seja, têm parte com os mortos. 


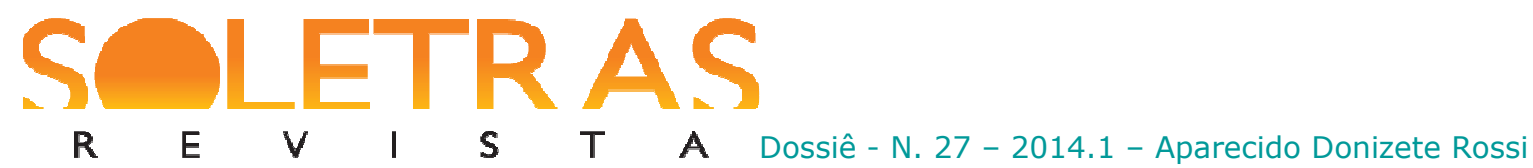

Os ecos de tais acepções encontram ressonância em culturas e literaturas tão diversas quanto a celta e a iorubá, ambas detentoras de grande influência sobre a ficção gótica ${ }^{4}$. Entre os celtas, a celebração da festa de Samhain, a qual demarcava o final da colheita e que foi, atualmente, ressignificada na tradição do Halloween, tinha como um de seus pontos fundamentais a oferenda de alimentos, especialmente coisas doces (frutas e bolos), e o beber em homenagem aos mortos para que estes não arrastassem os vivos para as searas do Além. Esses alimentos eram colocados em encruzilhadas, locais onde se acreditava que os mortos se reuniam entre o anoitecer do dia 31 de outubro (dia de Samhain) e o anoitecer do dia 01 de novembro antes de perambularem pelo mundo dos vivos.

Já na religião e cultura iorubá, bem como em seus desdobramentos no Candomblé e Umbanda brasileiros, na Santería cubana e no Vodu haitiano, a cada um dos orixás, os deuses iorubás, devem ser oferecidas, nos seus rituais, as bebidas e comidas que lhes são caras. Dentre os orixás, um deles se destaca, pois deve ser cultuado em primeiro lugar, inclusive antes do ritual dedicado a outro orixá. Seu nome é Exu, a quem se pode ou se deve oferecer mel, farinha, bebida alcoólica, sal (que tem parte com a água), azeite de dendê (o uso de óleo em um ritual religioso encontra referência na versão da Nekyia presente na Eneida, como se observará abaixo) e, dependendo da situação, sangue sacrificial de animais. Esse orixá é o mensageiro, aquele que transita por todos os lugares e mundos da criação, mas também é o deus brincalhão, o coringa (jester, trickster, o Louco das cartas do Tarô), articulador de engodos e símbolo da esperteza. Sua semelhança com Hermes é flagrante, e as religiões cristãs o interpretam, erroneamente, como um ser exclusivamente maligno, um demônio. Exu tem falanges que o seguem, compostas por espiritualidades que também se autodenominam exus. O ritual destinado a algumas dessas espiritualidades, as conhecidas como exus de rua, utiliza-se das mesmas oferendas dedicadas ao orixá Exu, com a diferença de que devem ser depositadas em encruzilhadas ou atiradas em caminhos públicos.

Em suma, o ritual de necromancia engastado em um texto primordial como a Odisseia é, talvez, o que possibilita a existência e a força da ficção gótica no decorrer da história da literatura e das culturas ocidentais, força que advém do fato de que a Nekyia presente na obra de Homero estabelece as Trevas como elemento escritural, como processo gerador e

\footnotetext{
${ }^{4}$ No caso da cultura e literatura iorubanas, seu uso é bastante recente no contexto do Gótico e muito particular às manifestações desse tipo de ficção no Brasil, na qual tem se revelado uma fonte muito prolífica. Anjo: a face do Mal (2004), de Nelson Magrini, e A saga de Orum: os guerreiros sagrados (2014), de Lara Orlow, são exemplos da aproximação entre o Gótico e a mitologia dos orixás. 


\section{SOLETR AS \\ R E V I $\quad$ S $\quad$ T A Dossiê - N. 27-2014.1-Aparecido Donizete Rossi}

subversor de significação, uma vez que é graças aos seus poderes que o luminoso Odisseu conseguirá chegar em casa e retomar uma vida digna. É também graças a esses mesmos poderes que a própria possibilidade de ler a Odisseia se abre ainda hoje, contemporaneamente, depois de passados quase três mil anos, e não se deve esquecer que ler, como a Nekyia, é, em si, um ato, um processo de invocação, de acesso, da textualidade enquanto tecido de significação que é construído e desconstruído no momento em que é lido, gesto que é metaforizado pelo que fazia Penélope, esposa de Odisseu, com o sudário de Laertes na mesma Odisseia. Mais do que metáforas de um gesto de significação que se volta a si mesmo para revelar que "não há fora-de-texto" (DERRIDA, 2004, p. 194, grifo do autor), as Trevas são, especialmente nessa obra homérica, mas também, e particularmente, em toda a ficção gótica por ela fundada, a própria possibilidade do signo e da significação.

É sob essa perspectiva que a Nekyia de Odisseu se transmigra também na disseminação das Trevas por entre, e por meio de, alguns dos elementos temático-estruturais mais importantes e recorrentes da ficção gótica, suas Artes das Trevas, suas convenções, suas diversas Arquiteturas do Medo: os usos e representações do sobrenatural maligno, a criação e articulação da atmosfera gótica como base para a geração do medo, o trabalho com os monstros e as monstruosidades, os usos da bruxaria e da magia negra, a libertação das forças infernais reprimidas, a permanente atualização da necromancia (à qual estão atrelados todos os fantasmas, espectros e mortos-vivos que povoam o imaginário), o jogo com as sombras e a noite, as representações da loucura e as maquinações da ilusão, as distopias e as representações de futuros apocalípticos, a estética cyberpunk e as representações de futuros pós-apocalípticos. Em suma, todos os aspectos arquitetônicos de uma ficção que objetive trabalhar com o que é obscuro, proibido, enigmático, unheimlich, assustador.

Por certo que a Nekyia homérica não é a única raiz do Gótico, ainda que seja seu filamento primevo. De certa forma, toda ficção que se articula em torno da figura do herói, seja essa ficção épica ou não, apresenta uma Nekyia e/ou a conjunção Nekyia+Katabasis+Anabasis, o que torna o Gótico um aspecto inseparável dessa tradição. É o que ocorre, por exemplo, no canto VI da Eneida, de Virgílio. Nesse canto, Enéias anseia descer ao Submundo para conversar uma última vez com Anquises, seu pai, que, como Tirésias, também representa a sabedoria. A única maneira de fazê-lo é consultando e pedindo auxílio à Sibila de Cumas, que, por meio de um ritual de magia negra semelhante ao que se encontra na Odisseia, porém mais violento, lhe abre as portas do mundo dos mortos: 
De amplo hiato espelunca alta e lapídea,

Fusca selva a munia e lago imano,

Sobre o qual transvoar impune as aves

Nunca puderam, tal das fauces turvas

Odor exala pelo azul convexo;

Donde em grego o lugar chamou-se Aornon.

Quatro almalhos ali terginigrantes

A vate [a Sibila] expõe, nos testos vinho entorna,

Entre os cornos tosquia, e em sacro fogo

Lança em primícias o pêlo; vocifera

Hécate no Érebo e nos céus potente.

Facas ao sangradouro, alguns em taças

Cruor tépido aparam. Mesmo à espada

Enéias das Eumênides à madre

E à Terra irmã cordeira preta imola,

E a ti fere, Prosérpina, uma toura;

Alça da Estige ao rei noturnas aras;

Em holocausto as vísceras bovinas,

Derrama azeite no debulho ardente.

Eis sob os pés, ao primo albor do dia,

A remugir o chão, mover-se os cumes

Do arvoredo; na sombra, ao vir a déia,

Surde um canino uivar. "Profanos, longe;

Oh! longe deste bosque, a vate exclama:

Tu, Frígio (aqui denodo, aqui firmeza),

Desembainha o ferro, a estrada invade."

(VIRGÍlLIO, 2008, p. 237 - 238).

Três aspectos chamam a atenção nessa Nekyia: primeiramente, sua violência e as invocações das divindades das Trevas. O ritual perpetrado pela Sibila de Cumas envolve o sacrifício de quatro bovinos, o dobro do que Odisseu sacrificou, além de uma vaca e de uma cordeira negra. Não há, como no caso de Odisseu, apenas a promessa de sacrificar, posteriormente, uma vaca estéril aos mortos e um carneiro negro a Tirésias, o que constitui uma espécie de garantia da real eficácia da cerimônia. Na Nekyia virgiliana, todos os sacrifícios são feitos durante o ritual, o que o torna bastante sangrento, uma cena de horror explícito (uma das primeiras, senão a primeira, na literatura ocidental) enfatizada pelo escorrer do sangue nas taças e pela exposição das facas ritualísticas e da espada de Enéias utilizadas nas mortes. Os quatro bovinos eram bezerros de dorso negro ("almalhos [...] terginigrantes”) que foram sacrificados à Hécate, deusa da lua negra, senhora da noite escura e da bruxaria, de quem Medéia era sacerdotisa. A vaca foi sacrificada à Prosérpina, nome latino de Perséfone, e a cordeira negra à Nix (“das Eumênides à madre”, ou seja, à mãe das Erínias, que, segundo Ésquilo na terceira peça da Oresteia, intitulada Eumênides, são filhas da própria Noite) e à Gaia (“à Terra irmã”, a irmã de Nix, Gaia). Hades não é mencionado no 


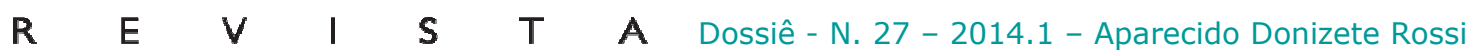

ritual, o que evidencia uma característica recorrente não apenas da ficção gótica, mas também da maior parte da ficção e das artes ocidentais, qual seja o fato de que a bruxaria é um artifício especial e particularmente feminino. Na versão de Virgílio, a Nekyia é realizada por uma mulher e as forças invocadas durante o ritual são exclusivamente femininas. Essa cena, juntamente das feitiçarias de Circe na Odisseia e de Medéia nas peças homônimas (a de Eurípides e a de Sêneca), constituem os primórdios da bruxaria na ficção gótica e nas artes e culturas ocidentais.

Um segundo aspecto que se destaca na Nekyia virgiliana é a criação de uma ambiência gótica para o ritual. O local onde reside a Sibila é uma caverna alta e rochosa ("espelunca alta e lapídea") em uma ampla fenda (“amplo hiato") protegida por uma floresta escura ("fusca selva"), onde se encontra também um lago de grandes proporções ("lago imano"), cujas águas turvas exalam um odor que impede que as aves o sobrevoem. De acordo com a tradição, tratase do lago Averno, por onde fluía o rio Aqueronte, o rio do Hades que fica na fronteira entre o mundo dos vivos e o mundo dos mortos. Na tradição latina e entre os gregos da Magna Grécia (sul da Itália), o Averno era considerado a entrada para o Submundo/Hades. A Nekyia ocorre, portanto, em um ambiente de morte e devastação, local em que ressalta o fato de ser a residência do que contemporaneamente se poderia entender como uma bruxa.

A ambiência criada nessa passagem da Eneida é sombria e maligna, desoladora e mortal, assustadora até mesmo para Enéias, semideus e herói clássico que, depois da Nekyia, tem que entrar na caverna da Sibila para iniciar sua Katabasis+Anabasis, o que ele faz "com tímido passo" (VIRGÍlLIO, 2008, p. 238). Ainda que uma ambiência desse tipo, porém com elementos distintos, também envolva a Nekyia de Odisseu — " "...] quando o Sol se deitou e as estradas a sombra cobria / [...]/ Noite nociva se estende sem pausa por sobre esses míseros" (HOMERO, 2001, p. 190) —, é a cena virgiliana que ecoa diversas outras passagens na literatura em que a atmosfera e o cenário trabalham juntos para construir um ambiente assustador. A ambiência gótica presente na Nekyia virgiliana, juntamente de sua análoga na Odisseia, está na base do que seria considerado, muito mais tarde, uma das características fundamentais da ficção de terror e horror: a criação da atmosfera como articuladora do medo.

O terceiro e último aspecto a chamar a atenção na Nekyia presente na Eneida é sua relação com a Katabasis+Anabasis do herói, o que a torna diferente da Nekyia de Odisseu no que concerne a seus propósitos. O ritual homérico é uma invocação dos mortos com o único intuito de questioná-los sobre o futuro, enquanto o ritual virgiliano é o primeiro passo para a 


\section{SOLETR AS \\ R E V I $\quad$ S $\quad$ T A Dossiê - N. 27-2014.1-Aparecido Donizete Rossi}

viagem (ida e vinda) de Enéias ao Hades. A Nekyia virgiliana vai além de um ritual de necromancia ao se configurar como a abertura que permite a um ser vivo adentrar o mundo dos mortos, o que para os gregos resultaria na geração de uma hybris (v̋bpıc). É interessante notar que o canto VI da Eneida traz, em um poema épico, fundador de uma língua e de uma cultura, a Nekyia diretamente relacionada à Katabasis+Anabasis, pois tal fato expressa uma mudança marcante no imaginário humano em relação às Trevas e ao mundo dos mortos: o gesto de invocar os mortos para questioná-los sobre o desconhecido já não é mais metáfora suficiente para a busca humana da compreensão dos mistérios da existência, uma vez que se é possível abrir a passagem entre os dois lados do véu de Ísis, também é possível transitar por esses dois lados. Logo, emerge a possibilidade de, por meio do imaginário, forma de conhecimento tão eficaz quanto a ciência, adentrar no mundo do desconhecido.

À época de Virgílio, portanto, o imaginário humano já tinha despertado sua curiosidade em tentar descobrir o que havia no mundo dos mortos, se esse mundo era diferente (e em quê era diferente) do mundo dos vivos, se esse mundo era uma possibilidade da existência. O que se poderia chamar de Impulso das Trevas havia contaminado esse imaginário, e a Nekyia havia se transmutado em algo outro: para além de ser um medium entre conhecimento (o mundo dos vivos) e sabedoria (o mundo dos mortos), ela se tornara um portal místico, um processo de acesso entre duas dimensões cosmogônicas, entre vida e morte, entre realidade e imaginário, entre visível e invisível, entre Luz e Trevas, entre o Mundo Médio (a Terra Média, o mundo dos humanos mortais) e os outros planos da existência (Céu, Inferno, Purgatório e diversas outras denominações encontrados nas mitologias nórdica, celta, egípcia, hindu etc.). A Nekyia havia se tornado representação da busca humana pelo conhecimento oculto, mais propriamente uma metáfora das Trevas.

Por certo que idealizações do Além sempre existiram na literatura, nos mitos, nas religiões e nas culturas que fundaram o Ocidente, mas é com o canto VI da Eneida que o mundo dos mortos começa a ganhar plasticidade, detalhes, vida; enfim, uma descrição não apenas pontual, como ocorre nos mitos, mas cosmogônica. O mundo dos mortos ganha espacialidade e contornos próprios, torna-se existente, uma dimensão do cosmos, tão concebível quanto o mundo dos vivos. Com o advento da religião e da cultura cristãs, tal dimensão ganha o estatuto de verdade e uma estrutura calcada na hierarquia e na oposição dialética entre duas noções subjetivas de valor, bem e mal, as quais não existiam até então. Quando a cultura e a sociedade romanas entraram em declínio, quando o império romano 


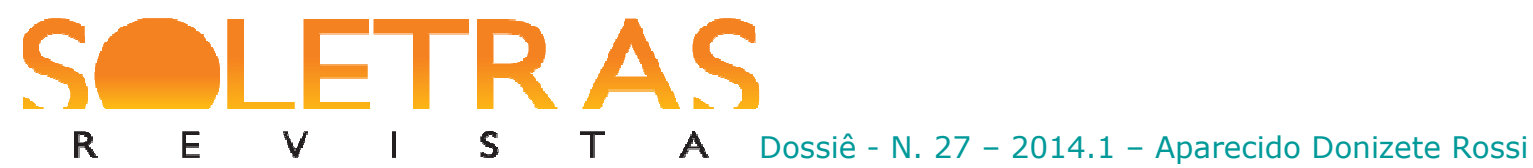

atingiu seu crepúsculo e tudo que restava das culturas antigas eram as culturas bárbaras, quando dez séculos se colocavam à frente da germinação e desenvolvimento das sementes plantadas pela cultura greco-romana em meio às suas próprias cinzas, o mundo dos mortos já detinha uma arquitetura demasiado humana, extremamente maniqueísta, já afastada da visão cosmogônica e holística do mundo antigo e assentada sobre os preceitos dominantes da nova fé: Céu, local onde reside tudo que é bom, e Inferno, local onde habita tudo que é mau.

Mas, estranhamente, é o Inferno que continuará chamando a atenção do imaginário humano, não o Céu, e é por meio das representações do Inferno que as Trevas sobreviverão incólumes às perseguições, expurgos e exorcismos contra elas perpetrados pelo Cristianismo, salvaguardando a ficção gótica da extinção e fazendo-a alimentar-se da incompreensão, da cegueira de espírito, da ignorância, dos derramamentos infundados de sangue, das fogueiras da Inquisição, do entendimento de mundo enviesado e preconceituoso imposto pela Igreja Católica, enfim, do manto do medo que encobriu o Ocidente durante a Baixa Idade Média, a Idade das Trevas. Foi nesse contexto, uma era de desejo e repulsa na qual se tinha, junto dos barbarismos (no mal sentido do termo), uma contraditória sensação de organicidade do mundo, que a ficção gótica voltou à tumba e nela foi novamente gestada, renovou-se e ganhou novas forças, forças sacrílegas, para que pudesse retornar, com a experiência mística dos conhecimentos e da sabedoria encerrados nos segredos que somente o que desce ao Inferno e dele retorna é capaz de decifrar, na emergência do romance gótico inglês.

\subsection{Os Infernos}

A primeira representação arquitetônica (des) agregadora, artística e literária, geradora e subversora de significação, de um dos mais prolíficos e impactantes cenários góticos possibilitados pelas Trevas é a que se encontra no primeiro livro d'A Divina comédia, de Dante Alighieri. O Inferno de Dante é, talvez, a progênie da nova e longa gestação pela qual passou a ficção gótica durante os dez séculos que compreendem a Baixa Idade Média. Não por acaso, ele é um dos textos fundadores do Renascimento, momento no qual as Trevas ganharão status de arte, como atestam Caravaggio, Michelangelo, Da Vinci, Spenser, Shakespeare, Marlowe, dentre tantos outros, bem como o surgimento da própria arquitetura gótica, a qual suscitaria a resposta negativa materializada na arquitetura românica. 


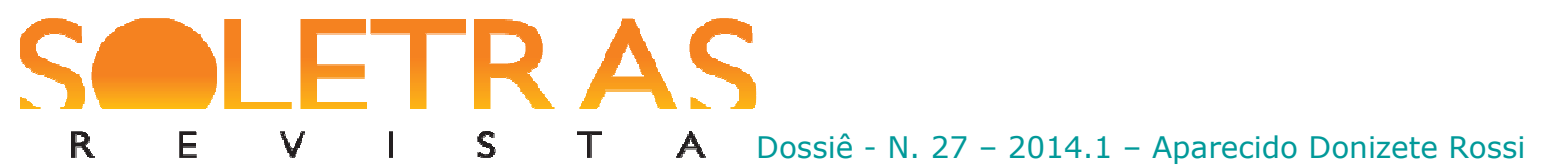

Utilizando-se de uma concepção híbrida articulada e suavizada por um lirismo de grande refinamento, Dante constrói sua imagem do Inferno, até hoje tida como inigualável, aproximando aporeticamente elementos da cultura, mitologia, arte e literatura greco-romanas com os preceitos do Cristianismo católico. Por conseguinte, é possível encontrar, nesse espaço estruturado em círculos dentro de um cone - uma pirâmide invertida, base da estrela de cinco pontas invertida, um dos símbolos das Trevas - um papa em um círculo e centauros no círculo vizinho.

A Nekyia não poderia deixar de estar presente em um texto desse porte, porém já de maneira renovada, representacional e metafórica, não mais a descrição de um ritual como se observa na Odisseia e na Eneida. O próprio Dante, autor, eu lírico e uma das personagens principais do poema, guiado pelo espectro de Virgílio, seu mestre inspirador tornado um psicopompo na obra, é quem faz a viagem de ida e vinda por entre o mundo dos mortos, cuja primeira parte constitui-se no reino inferior, o Inferno. Dante encontra o espectro de Virgílio no limiar entre o mundo dos vivos e o mundo dos mortos, um lugar onde há floresta e montanha, similar à morada da Sibila que o próprio Virgílio arquitetou na Eneida, e é conduzido pelo poeta latino até as portas do Inferno, onde sua atenção recai, de pronto, na inscrição escurecida que se encontra no topo dessas portas:

\section{VAI-SE POR MIM À CIDADE DOLENTE, VAI-SE POR MIM À SEMPITERNA DOR, VAI-SE POR MIM ENTRE A PERDIDA GENTE. \\ MOVEU JUSTIÇA O MEU ALTO FEITOR, FEZ-ME A DIVINA POTESTADE, MAIS O SUPREMO SABER E O PRIMO AMOR. \\ ANTES DE MIM NÃO FOI CRIADO MAIS NADA SENÃO ETERNO, E ETERNA EU DURO. DEIXAI TODA ESPERANÇA, Ó VÓS QUE ENTRAIS. (ALIGHIERI, 1998, p. 37).}

Nesta que é uma das passagens mais conhecidas do Inferno dantesco, observa-se, literalmente, a Nekyia transmutada em portal místico entre duas dimensões do cosmos, de modo que seus elementos ritualísticos, antes representados por meio de alimentos e sacrifícios de animais, agora estão fixados em uma inscrição, estão transformados em linguagem, são a própria textualidade da obra. As Trevas estão materializadas nessa inscrição, que detém uma tríplice função: permitir uma escolha ao vivente (a de voltar ou continuar); avisar-lhe sobre o que vai encontrar se decidir prosseguir (a "cidade dolente", a "sempiterna dor", a "perdida 


\section{SOLETR AS \\ R E V I S T T A Dossiê-N. 27-2014.1-Aparecido Donizete Rossi}

gente", toda forma de sofrimento); e amaldiçoá-lo caso atravesse o umbral entre a vida e a morte ("Deixai toda esperança, ó vós que entrais"). O que se tem do outro lado do portal, o Inferno em si, é prova de que a sanha humana pelo conhecimento do oculto, dos mistérios e dos segredos que as Trevas podem revelar, não se detém nem mesmo diante de uma maldição que suprime do ser vivente justamente a essência da vida, a esperança.

Por trás da Nekyia materializada na rocha dos portais e tornada feitiço por meio da linguagem, o leitor cuja curiosidade e coragem são mais fortes que a ameaça imposta pela textualidade encontrará, pintado em sangue e sombras e cantado com a força e o encanto insuperáveis da terza rima, tudo que o imaginário humano foi capaz de criar para conceber a idéia de Inferno como espaço daquilo que é maligno: tortura, dor, sofrimento, estagnação, loucura, sombras, desespero, pecado, todos permeados pelo poder incontrolável e incompreensível do sobrenatural em sua manifestação tenebrosa. Terror, horror, pavor e abjeção estão, no Inferno de Dante, a trabalho do sadomasoquismo que habita os recônditos mais sombrios e insanos da mente humana, um sadomasoquismo que, no caso da obra em questão, é transformado em algo duplamente prazeroso, pois além do elemento de prazer psicofísico que já lhe é inerente, Dante lhe concedeu ainda o lirismo poético, o prazer do espírito e, com esse gesto, elevou-o ao estatuto de arte. Cabe ao mestre florentino, portanto, o mérito de ser o primeiro a tornar as Trevas uma forma de arte, e seu Inferno, uma das raízes mais importantes a surgir do filamento primevo que é a Nekyia homérica, se constitui na influência mais clássica e prolífica, sendo até considerado a raiz principal, de toda a ficção gótica anterior e posterior a $O$ castelo de Otranto.

O Inferno de Dante não é, evidentemente, a única ramificação infernal do filamento primevo. Há uma outra raiz, articulada sob a inspiração de Dante e de Virgílio, que se mostrou metáfora do próprio gesto de criar ficção gótica: o Inferno de Milton, presente na obra-prima do autor inglês, Paraíso perdido. Inteiramente calcado na concepção cristã do mundo dos mortos (Céu e Inferno em oposição, sendo o Céu superior ao Inferno), o texto miltônico propõe o relato de acontecimentos anteriores à perda do Paraíso por parte do casal edênico, Adão e Eva, os pais míticos da raça humana de acordo com o Gênesis bíblico. Tais acontecimentos também são a causa da perda do Paraíso, e foram arquitetados pela personificação cristã de todos os males: Satã, o anjo caído, nome que Lúcifer recebeu depois de se rebelar, ser expulso do Reino Celestial e cair, junto de seus seguidores, até atingir o fundo da existência, as "trevas exteriores" (MILTON, 2003, p. 27), o Inferno. 


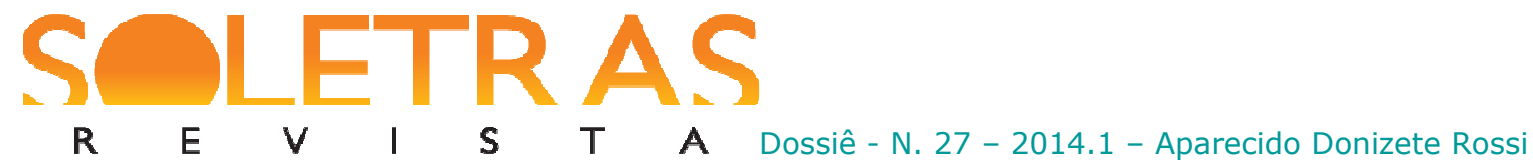

Diferentemente do Inferno de Dante - cuja estrutura de disposição dos círculos infernais está organizada em ordem crescente pelo teor dos pecados, ou seja, no primeiro círculo não estão exatamente pecadores, mas sim aqueles que não tiveram conhecimento do Deus cristão em suas vidas, enquanto que os últimos círculos são reservados aos pecados mais graves aos olhos do Cristianismo católico do século XIV, sendo que na última esfera do último círculo, chamada Giudecca, estão presos, no gelo absoluto (note-se que a punição suprema no Inferno dantesco dá-se por meio do gelo, e não do fogo), o arqui-traidor Lúcifer, descrito como uma monstruosidade gargulesca de três cabeças, cujas mandíbulas mastigam os outros traidores famosos: Judas, Brutus e Cassius -, no Inferno de Milton o leitor é de pronto lançado, logo depois das praxes iniciais de todo poema épico (dedicatória, invocação das musas e apresentação do tema), feitas de modo sumário pelo autor, no Inferno e diante do próprio Satã, que, no momento em que a narração começa, está se levantando e olhando ao redor do lago de fogo em que caíra para dar início à conclamação de seus asseclas, à organização do espaço infernal e à jura de vingança contra o Criador:

Pelo espaço que abrange no orbe humano

Nove vezes o dia e nove a noite,

Ele [Satã] com sua multidão horrenda [os demais anjos caídos],

A cair estiveram derrotados

Apesar de imortais, e confundidos

Rolaram nos cachões de um mar de fogo.

Sua condenação, porém, o guarda

Para mais fero horror: e vendo agora

Perdida a glória, perenal a pena,

Este duplo prospecto na alma o punge.

Lança em roda ele então os tristes olhos

Que imensa dor e desalento atestam,

Soberba empedernida, ódio constante:

Eis quando de improviso vê, contempla,

Tão longe como os anjos ver costumam,

A terrível mansão, torva, espantosa,

Prisão de horror que imensa se arredonda

Ardendo como amplíssima fornalha.

Mas luz nenhuma dessas flamas se ergue;

Vertem somente escuridão visível

Que baste a pôr patente o hórrido quadro

Destas regiões de dor, medonhas trevas

Onde o repouso e a paz morar não podem,

Onde a esperança, que preside a tudo,

Nem sequer se lobriga: os desgraçados

Interminável aflição lacera

E de fogo um dilúvio alimentado

De enxofre abrasador, inconsumptível.

(MILTON, 2003, p. 26 - 27). 


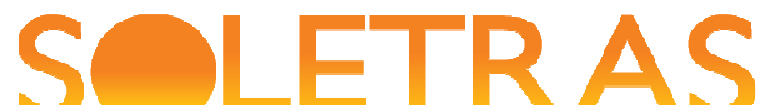 \\ R E V I S $\quad$ T $\quad$ A Dossiê-N. 27-2014.1-Aparecido Donizete Rossi}

Esse gesto de lançar o leitor diretamente no Inferno e diante da face de Satã torna o Inferno de Milton um texto de grande poder de impacto sobre o imaginário, inescapável, um texto que, uma vez que se comece a ler, já se está dentro do reino inferior do mundo dos mortos, reino que se torna, por meio da linguagem, um sempre-já Trevas. Não há rituais e nem avisos, pois não existem mais sequer indícios de uma Nekyia, a qual se transfigurou ela mesma na textualidade em si do poema, as Trevas em seu estado mais puro, coincorporação teratológica, "processo aberto e infinito, ao mesmo tempo de geração e de subversão de significados" (JOHNSON, 1995, p. 40, grifo da autora), escritura, o Mal. No Inferno miltônico, a Nekyia já se transmutou em Trevas, e as Trevas no próprio ato da leitura. O ritual de necromancia, a conjuração dos seres do Além em busca de sabedoria, é o próprio texto, o acontecimento da Nekyia, acontecimento da linguagem, só-feitiço, só-conjuração, no exato instante de sua leitura. Todo aquele que lê o Inferno miltônico, portanto, já tem Satã invocado a seu lado no instante em que lê a primeira palavra do poema; já posta, como reza o Salmo, "um acusador ${ }^{5}$ [...] à sua direita" (Salmo 109: 6, 1980, p. 1074). Em Milton, a Nekyia, a textualidade, é a epifania das Trevas, as quais se mostram também epifânicas ao leitor.

É em razão dessa característica escritural que o Inferno miltônico, diferente do dantesco, só pode ser considerado um espaço de sofrimento para os seres angélicos que nele caíram e que agora se encontram "Longe do excelso Deus, da luz empírea, / Distância tripla da que os homens julgam / Do centro do orbe à abóbada estrelada" (MILTON, 2003, p. 27), pois não há, nesse lugar, almas penadas de humanos desencarnados e nem o sadomasoquismo cantado liricamente. Há apenas as potestades que perderam sua condição angelical, mas não sua divindade. O Inferno de Milton é o local mais distante da emanação do Criador existente no cosmos, mas ainda assim um espaço divino, e a causa do sofrimento daqueles que o habitam é justamente essa distância e essa divindade, as quais, aporeticamente, no instante em que impõem isolamento e solipsismo, impulsionam os caídos a darem uma forma artística à materialidade do fogo e das Trevas, "escuridão visível” (id., ibid.), que os envolve. Sob os auspícios de Múlciber, outro nome para o latino Vulcano e para o grego Hefesto, eles criarão sua morada nos reinos infernais. Impulsionados pelas Trevas, eles farão do Inferno miltônico a morada das artes, do gesto de criar, do fazer artístico ao construírem, por meio do cântico e do trabalho manual, um local que concentra toda a tradição artística ocidental não apenas na

\footnotetext{
5 A palavra hebraica para "acusador" e "adversário" é שָָָ, Satã quando transcrita em caracteres ocidentais e adaptada à língua portuguesa. 


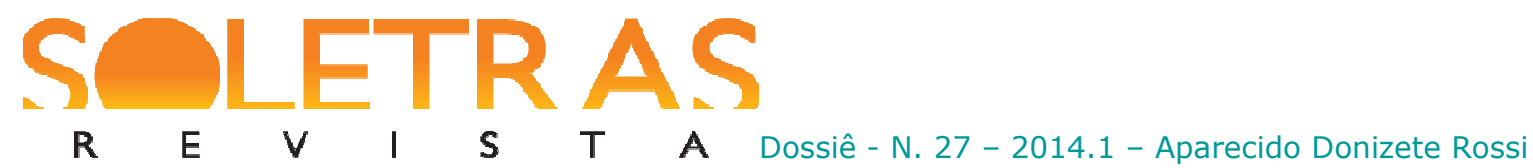

sua arquitetura, mas também naqueles que a habitam, seres cultuados, como listado ao longo de todo o primeiro canto do Paraíso perdido, entre todas as culturas e línguas do mundo conhecido, mas que foram denominados demônios pelo entendimento enviesado do Cristianismo. Eis a razão pela qual o Inferno miltônico é metáfora do próprio gesto de criar ficção gótica, do fazer gótico:

Logo a compasso de um concerto insigne

De suave instrumental, de magas vozes,

Uma fábrica imensa sobre a terra,

Em ar de exalação, eis vai surgindo;

E fica em breve um templo majestoso

Rodeado de pilastras, que sustentam

Vasta série de dóricas colunas

Com arquitraves de ouro guarnecidas;

De relevos magníficos se adorna

Da cornija e do friso o brilho ingente;

É todo o teto de ouro cinzelado;

E o suntuoso edifício, altivo, imenso,

Tem fixa a base em rocha de diamante.

(Nunca o Grão-Cairo, Babilônia nunca

Tal riqueza, tal pompa, tal grandeza

Puderam igualar nos altos templos

Dos pátrios deuses seus, Belo e Serápis,

Nem de seus reis nos paços estupendos

Quando um mais que outro na riqueza e luxo

A Assíria, o Egito, se julgavam ambos.)

Eis se abrem, par em par, as brônzeas portas:

Lá dentro espaço amplíssimo se avista

Sobre o polido e plano pavimento.

Da cúpula lustrosa penduradas

Por magia sutil descem brilhantes

Em fileiras diversas, como estrelas,

Candelabros e lâmpadas fornidas

De asfalto e nafta que de si produzem

Luz semelhante à que dos Céus se espalha.

(MILTON, 2003, p. 59 - 60).

O belo e o sublime, o poético, residem no Inferno de Milton, e o resultado dessa arquitetura na qual a Luz habita a Sombra e a Sombra se torna Luz, o Céu resplandece no Inferno e o Inferno resplandece como o Céu, será a transformação da ficção gótica em poesia, pois o Inferno e o Satã miltônicos servirão de inspiração direta para, em meio à imensa popularidade do romance gótico no final do século XVIII e início do XIX, o florescimento do Romantismo na mesma Inglaterra que é pátria de Milton e de Horace Walpole. O Satã de Milton, no entanto, não será uma figura restrita apenas à poesia e ao Romantismo, mas, por ser a imagem do arqui-inimigo de Deus mais bem articulada de que dispõe a literatura 


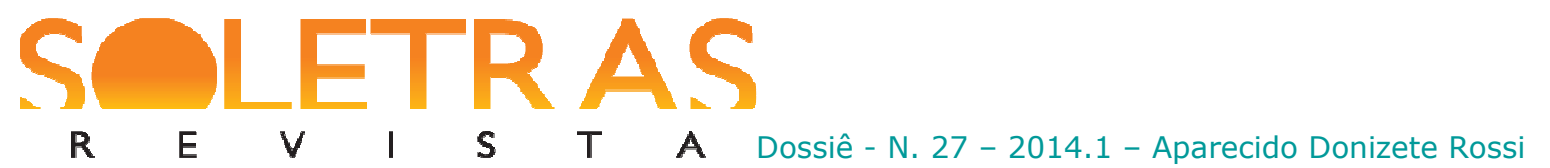

ocidental, se tornará a referência fundamental para toda e qualquer representação do lado maléfico e demoníaco, do lado tenebroso, do ser humano na ficção. Satã assumirá muitos rostos na tradição gótica que sucede ao Paraíso perdido: vilão, anti-herói, inimigo, monstruosidade. Nunca perderá, no entanto, o carácter indecidível que implica ser a paradoxal mão esquerda de Deus, de onde provém a força que, estranhamente, sua presença imprime à toda obra e a todo gesto de leitura que o invoque.

À guisa de uma possível conclusão para essa breve escavação de algumas raízes da ficção gótica espalhadas pela história literária e cultural e pelo imaginário do ocidente, podese reconhecer que muita coisa ainda ficou por ser dita, não só sobre os textos aqui rapidamente analisados, mas também sobre muitos outros textos literários sumamente importantes que, infelizmente, não puderam ganhar a atenção que merecem nestas poucas páginas. Uma omissão flagrante é Shakespeare, um necromante tão habilidoso na invocação dos mortos e nos usos dos poderes das Trevas quanto Odisseu ou a Sibila de Cumas, como se pode observar em Hamlet e Macbeth. Muito também ficou por ser dito sobre o semi-conceito de Trevas, que merece uma reflexão mais ampla. Por ora, como fechamento para as elucubrações aqui realizadas, bastam as palavras de William Collins em sua "Ode to Fear": "Dark power, with shuddering meek submitted thought, / Be mine, to read the visions old, / Which thy awakening bards have told" (apud BOTTING, 2014, p. 33).

\section{Referências bibliográficas:}

ALIGHIERI, Dante. A divina comédia: Inferno. Trad. Italo Eugenio Mauro. Edição bilíngue italiano-português. São Paulo: Editora 34, 1998.

BOTTING, Fred. Gothic. 2. ed. London: New York: Routledge, 2014 (The New Critical Idiom).

DERRIDA, Jacques. Gramatologia. Trad. Miriam Chnaiderman e Renato Janine Ribeiro. 2. ed. São Paulo: Perspectiva, 2004 (Estudos, 16).

Some Statements and Truisms about Neologisms, Newisms, Postisms, Parasitisms, and Other Small Seismisms. Trad. Anne Tomiche. In: CARROLL, David (ed.). The States of "Theory": History, Art, and Critical Discourse. New York: Columbia University Press, 1990, p. 63 - 94 (Irvine Studies in the Humanities).

FARIA, Ernesto. Dicionário escolar latino-português. Rio de Janeiro: Ministério da Educação e Cultura, 1955. 


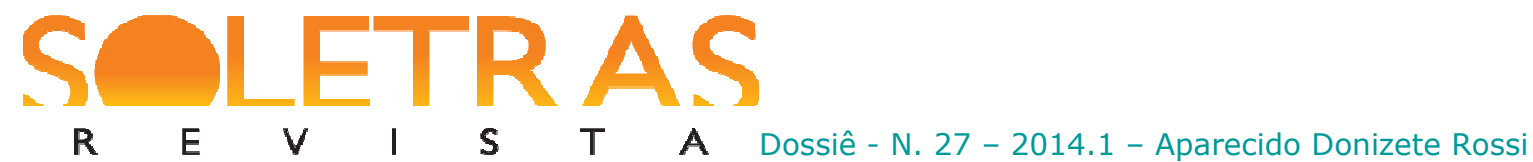

FOUCAULT, Michel. Prefácio à transgressão. In: . Estética: literatura e pintura, música e cinema. Seleção e organização de Manoel Barros da Motta. Trad. Inês Autran Dourado Barbosa. 2. ed. Rio de Janeiro: Forense Universitária, 2009, p. 28 - 46 (Ditos \& Escritos, III).

HOMERO. Odisseia. Trad. Carlos Alberto Nunes. 3. ed. Rio de Janeiro: Ediouro, 2001.

JOHNSON, Barbara. Writing. In: LENTRICCHIA, Frank; McLAUGHLIN, Thomas (Eds.). Critical Terms for Literary Study. 2. ed. Chicago; London: The University of Chicago Press, 1995 , p. $39-49$.

MILTON, John. Paraíso perdido. Trad. Antônio José Lima Leitão. São Paulo: Martin Claret, 2003 (Série Ouro, 16).

SALMO 109. In: A Bíblia de Jerusalém. São Paulo: Paulus, 1980, p. 1073 - 1075.

VIDAL, Ariovaldo José. Apresentação. In: WALPOLE, Horace. $O$ castelo de Otranto. Trad. Alberto Alexandre Martins. São Paulo: Nova Alexandria, 1996, p. 7 - 10.

VIRGÍLIO. Eneida brasileira: tradução poética da epopéia de Públio Virgílio Maro. Trad. Manuel Odorico Mendes. Edição bilíngue latim-português. Campinas, SP: Editora da UNICAMP, 2008.

\title{
Before Otranto: notes on a pré-history of the gothic in literature
}

\begin{abstract}
Departing from Ariovaldo Vidal's statement, in his foreword to the Brazilian translation of The Castle of Otranto, that the Gothic sources were spread upon literary and social history waiting for someone (Horace Walpole) to collect them in order to create a new literary genre, and connecting imagination to such statement, my purpose in this paper is to make some notes on what would possibly be these sources referred by Vidal. By the means of thinking on the Darkness as a semi-concept, a perspective largely inspired in Fred Botting's Gothic (2014), I intend to look for the origins of Gothic fiction in texts by Homer, Virgil, Dante, and Milton.
\end{abstract}

Key words: Gothic. Imagination. British Literature. Classic Literature.

Recebido em: 15 de maio de 2014.

Aprovado em: 26 de agosto de 2014. 